Volume 1 Nomor 22021

http://journal.febubhara-sby.org/bharanomics

ISSN (Online): 2774-7190

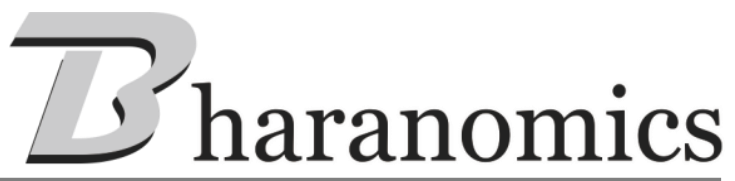

\title{
Dampak Ketimpangan Pendapatan, Tata Kelola Pemerintahan dan Korupsi terhadap Tingkat Kemiskinan di Indonesia
}

\author{
*Lailatul Khasanah \\ Jurusan Ekonomi Pembangunan, Fakultas Ekonomi dan Bisnis \\ Universitas Bhayangkara Surabaya, Indonesia
}

DOI: 10.46821/bharanomics.v1i2.156

\begin{abstract}
Abstrak
Kemiskinan menjadi salah satu penyakit perekonomian yang sulit dihilangkan di hampir setiap Negara, terlebih lagi di Negara berkembang seperti Indonesia yang masih memiliki tingkat kemiskinan cukup tinggi dibandingkan dengan beberapa Negara disekitarnya. Terdapat isu menarik berkaitan dengan masalah kemiskinan di Indonesia yaitu adanya ketimpangan pendapatan.Namun tidak disertai dengan peningkatan penurunan angka kemiskinan. Salah satu indikasi yang menyebabkan sulitnya menurunkan angka kemiskinan adalah adanya kecurangan-kecurangan dilakukan pemerintah. Misalnya dengan melakukan praktek korupsi. Penelitian ini bertujuan untuk melihat dan menganalisis dampak ketimpangan pendapatan, tata kelola pemerintahan dan korupsi terhadap tingkat kemiskinan di Indonesia. Metode yang digunakan adalah SPSS. Hasil estimasi menunjukkan bahwa ketimpangan pendapatan, tata kelola pemerintahan dan korupsi masing-masing mempunyai pengaruh signifikan terhadap tingkat kemiskinan.
\end{abstract}

Kata kunci: $\quad$ Ketimpangan Pendapatan, Tata Kelola Pemerintahan, Korupsi

\begin{abstract}
:
Poverty is one of the economic diseases that is difficult to be eliminated in almost every country, especially in developing countries such as Indonesia, which still has a relatively high poverty rate compared to several countries around it. There are interesting issues relating to the problem of poverty in Indonesia, namely the existence accompanied by an increase in poverty reduction. One indication that makes it difficult to reduce poverty is the fraud committed by the government. For example by practicing corruption. This study aims to look at and analyze the impact of income inequality, governance and corruption on poverty levels in Indonesia. The method used is SPSS. Estimation results show that income inequality, governance and corruption each have a significant influence on poverty levels.
\end{abstract}

Keywords: Income Inequality, Governance, Corruption

\section{PENDAHULUAN}

Kemiskinan menjadi salah satu penyakit perekonomian yang sulit dihilangkan di hampir setiap Negara, terlebih lagi di Negara berkembang seperti Indonesia yang masih memiliki tingkat kemiskinan cukup tinggi dibandingkan dengan beberapa Negara disekitarnya. Indonesia merupakan salah satu Negara berkembang yang memiliki jumlah penduduk terpadat nomer empat di dunia setelah Amerika Serikat, China, dan India. Dengan jumlah penduduk yang diperkirakan hampir mencapai 262 juta jiwa.

Try Haryono dalam tulisannya yang berjudul Kemiskinan yang Dieksploitasi menyebutkan bahwa salah satu penyebab kemiskinan yang terjadi di Indonesia adalah terjadinya kecurangan-kecurangan yang dilakukan oleh pemerintah. Praktek korupsi yang terjadi dianggap sebagai penyebab sulitnya menurunkan angka kemiskinan di

*Corresponding Author:

Hal: $75-81$

Email: lalaaksnh@gmail.com 
Indonesia.Adanya korupsi menyebabkan anggaran yang sedianya digunakan untuk meningkatkan mutu pendidikan, menyediakan fasilitas kesehatan, menyediakan infrastruktur dan memperluas lapangan kerja menguap ke tangan-tangan yang tidak bertanggung jawab.Hal ini menyebabkan kondisi penduduk miskin makin terpuruk (Korupsi yang Memiskinkan, Maria Hartiningsih (Ed), 2011).

Korupsi bukan merupakan hal baru yang terjadi di Negara berkembang terutama di Indonesia. Maraknya kasus korupsi di Indonesia tidak hanya terjadi di kota - kota besar tetapi juga terjadi di tingkat daerah dan kabupaten. The USAID Handbook for Fighting Corruption (1999) menyatakan bahwa korupsi meliputi pelanggaran sepihak oleh pejabat pemerintah seperti penggelapan dan nepotisme, serta pelanggaran menghubungkan aktor publik dan swasta seperti penyuapan, pemerasan dan penipuan. Menurut World Bank (2000), Korupsi merupakan salah satu hambatan terbesar dalam pertumbuhan ekonomi, karena korupsi mendistorsi hukum dan melemahkan fondasi institusi yang menyokong pertumbuhan ekonomi.

Selain Korupsi, tata kelola pemerintahan juga mempengaruhi tingkat kemiskinan. Dalam hal ini, masalah korupsi diasumsikan memiliki hubungan yang erat dengan masalah tata kelola pemerintahan. Adanya tata kelola pemerintahan yang buruk memang tidak selalu menunjukkan adanya korupsi. Namun, adanya tata kelola pemerintahan yang buruk akan meningkatkan probabilitas untuk terjadinya praktek korupsi.

Faktor lain yang mempengaruhi tingkat kemiskinan adalah Ketimpangan Pendapatan yang diukur dengan koefisien gini. Ketimpangan pendapatan yang besar merupakan masalah bagi sebagian besar Negara yang sedang berkembang, tidak terkecuali dengan Indonesia.

Ketimpangan pendapatan adalah suatu kondisi dimana distribusi pendapatan

yang diterima masyarakat tidak merata. Ketimpangan pendapatan ditentukan oleh tingkat pembangunan heterogenetis etnis, ketimpangan yang berkaitan dengan kediktatoran dan pemerintah yang gagal menghargai property rights (Blaeser, 2006)

Sesuai latar belakang yang telah dibahas diatas, maka dapat dirumuskan beberapa permasalahan dalam penelitian ini yaitu: Apakah ketimpangan pendapatan, tata kelola pemerintahan dan korupsi secara parsial mempunyai pengaruhsignifikan terhadap tingkat kemiskinan di Indonesia. Apakah ketimpangan pendapatan, tata kelola pemerintahan dan korupsi secara simultan mempunyai pengaruh signifikan terhadap tingkat kemiskinan di Indonesia. Manakah diantara ketimpangan pendapatan, tata kelola pemerintahan dan korupsi yang berpengaruh dominan.

\section{TINJAUAN PUSTAKA}

\section{Pengertian Kemiskinan}

Ritongga (2003:1) memberikan definisi bahwa kemiskinan adalah kondisi kehidupan serba kekurangan yang dialami seorang atau rumah tangga sehingga tidak mampu memenuhi kebutuhan minimal atau yang layak bagi kehidupannya. Kebutuhan dasar minimal yang dimaksud adalah yang berkaitan dengan kebutuhan pangan, sandang, perumahan dan kebutuhan sosial yang diperlukan oleh penduduk atau rumah tangga untuk memenuhi kebutuhan hidupnya secara layak. 
Dari sisi ekonomi terdapat tiga penyebab kemiskinan.Pertama, kemiskinan timbul akibat adanya perbedaan kepemilikan sumberdaya yang berdampak pada ketimpangan distribusi pendapatan.Bahkan, sumberdaya yang dimiliki orang miskin sangat terbatas dan berkualitas rendah.Kedua, akibat rendahnya pendidikan, nasib yang kurang beruntung, diskriminasi atau faktor keturunan, menyebabkan kualitas sumber daya manusia yang rendah.Hal ini berdampak pada produktivitas dan tingkat upah yang rendah.Ketiga, perbedaan akses terhadap modal juga dapat menjadi salah satu penyebab kemiskinan (Kadji, 2012). Orang miskin cenderung tidak memiliki akses ke aset produktif utama yang diperlukan untuk keluar dari kemiskinan (Devereux \& Sharp, 2003).

\section{Ketimpangan Pendapatan}

Ketimpangan Pendapatan yang diukur melalui koefisien gini adalah perbedaan jumlah pendapatan yang diterima masyarakat sehingga mengakibatkan perbedaan pendapatan yang lebih besar antar golongan dalam masyarakat tersebut. Akibat dari perbedaan itu maka akan terlihat kesenjangan yaitu yang kaya akan semakin kaya dan sebaliknya yang miskin akan semakin terpuruk.

Koefisien Gini adalah persamaan ukuran ketimpangan dan bisa berbeda-beda dari nolyang mengindikasikan suatu kemerataan sempurna (perfect equality) sampai satu yang berarti suatu ketimpangan total (perfect inequality) dalam distribusi pendapatan dan pengeluaran

$\mathrm{G}=1-\mathrm{i} \sum \mathrm{Pi}(\mathrm{Qi}+\mathrm{Qi}-1) 10.000$

\section{Tata Kelola Pemerintahan}

Menurut Lembaga Administrasi Negara (2006:6) tata kelola pemerintahan sebagai penyelenggara pemerintah negara yang solid dan bertanggung jawab, serta efisien dan efektif dengan menjaga "kesinergisan" interaksi yang konstruktif diantara domain negara sektor swasta dan masyarakat (society).

Frederickson (2004:12) mengemukakan bahwa tata kelola pemerintah adalah konsep yang sangat penting, karena menghubungkan antara yuridiksi di satu sisi dan masalah sosial, teknologi, politik dan ekonomi di sisi lain. Untuk menganalisis kerangka kerja tata kelola pemerintahan menggunakan pendekatan dengan model sebagai berikut.

$\mathrm{O}=\mathrm{f}(\mathrm{E}, \mathrm{C}, \mathrm{T}, \mathrm{S}, \mathrm{M})$

\section{Korupsi}

Menurut Jeremy Pope (2002:97), bahwa korupsi sebagai penyalahgunaan kekuasaan dan kepercayaan untuk kepentingan pribadi atau perilaku tidak mematuhi prinsip mempertahankan jarak (keeping distance). Dalam artian dalam mengambil keputusan (decision making) di bidang ekonomi, apakah ini dilakukan oleh perorangan di sektor swasta atau oleh pejabat publik (elite), hubungan pribadi (personal relationship) atau keluarga tidak memainkan peranan.Dalam pengertian korupsi oleh Jeremy Pope ditekankan bahwa korupsi disebabkan oleh karena seseorang lalai dalam wacana mempertahankan jarak. 
Bharanomics

Vol. 1 No. 22021

Lailatul Khasanah, Tingkat Kemiskinan di Indonesia

\section{METODE PENELITIAN}

Metode yang digunakan dalam penelitian ini adalah metode kuantitatif. Penelitian ini dilakukan untuk menguji bagaimana pengaruh variabel Ketimpangan Pendapatan, Tata Kelola Pemerintahan dan Korupsi terhadap tingkat Kemiskinan di Indonesia serta mengukur seberapa besar pengaruh tersebut apabila ada.

Untuk menjawab pertanyaan peneltian mengenai faktor-faktor apa yang mempengaruhi proporsi tingkat kemiskinan dan untuk mendapatkan besaran pengaruh masing-masing faktor tersebut, dibentuk suatu model dengan menggunakan Regresi Linear Berganda dengan pendekatan estimasi kuadrat terkecil. Kemudian untuk pengujiannya dilakukan dengan uji asumsi klasik, koefisien determinasi dan uji hipotesis melalui program SPSS.

\section{HASIL DAN PEMBAHASAN}

Hasil pengujian uji asumsi klasik dilakukan terlebih dahulu sebelum dilakukan pengujian terhadap hipotesis penelitian. Pengujian ini dimaksutkan untuk mengetahui apakah model yang diajukan dalam penelitian ini dinyatakan lolos dari penyimpangan asumsi klasik. Uji asumsi klasik meliputi uji normalitas, uji heterokedastisitas dan uji autokorelasi. Hasil uji normalitas dapat diperolah dari nilai bantuan software SPSS 25.

\section{Uji Normalitas}

Keputusan terdestribusi normal tidaknya residual secara sederhana dengan membandingkan nilai Probabilitas JB (Jarque-Bera) hitung dengan tingkat alpha 0,05. Apabila Prob. JB hitung lebih besar dari 0,05 maka dapat disimpulkan bahwa residual terdestribusi dengan normal. Nilai Prob. JB hitung sebesar 0,183446 >0,05 sehingga dapat disimpulkan bahwa residual terdestribusi dengan normal yang artinya asumsi klasik tentang kenormalan telah terpenuhi.

Berdasarkan tabel 1 di atas maka dapat dijelaskan hasil uji normalitas dengan metode Kolmogorov Smirnov, nilai sig yang di peroleh adalah 0,094. Karena nilai sig nya $(0,094)$ lebih besar dari 0,05 artinya data berdistribusi normal. Nilai Multikolinearitas yang dapat dilihat dari tabel 2 .

Tabel 1

Hasil Uji Normalitas

\begin{tabular}{ll}
\hline Test statistics &, 099 \\
\hline Asym sig & 094 \\
\hline
\end{tabular}

Sumber : Data Diolah, 2020

Tabel 2

Uji Multikolinearitas

\begin{tabular}{ccccc}
\hline Model & $\mathrm{R}$ & R square & Adjstd Rsquare & Std EROR \\
\hline 1 &, 484 &, 234 &, 198 &, 3583363 \\
\hline
\end{tabular}

Sumber : Data Diolah, 2020 
Tabel 3

Uji Hetrokedastisitas

\begin{tabular}{lll}
\hline Constant & Std Eror & Sig \\
\hline Ketimpangan Pendapatan (X1) &, 501 &, 423 \\
Tata Kelola Pemerintahan (X2) &, 024 &, 949 \\
Korupsi (X3) &, 100 &, 754 \\
\hline
\end{tabular}

Sumber : Data Diolah, 2020

Berdasarkan Tabel 2 maka, nilai $\mathrm{R}^{2}$ yang diperoleh adalah 0,234. Karena nilainya lebih rendah dari 0,8 artinya tidak ada multikolinieritas. Untuk uji Heterokedastisitas dapat dilihat dari Uji Glesjer yang dapat dilihat dari tabel 3.

Berdasarkan tabel 3 , variabel X1, X2, dan X3 masing-masing memiliki nilai sig yang lebih besar dari 0,05 sehingga disimpulkan bahwa tidak terdapat heteroskedastisitas dalam model regresi.

\section{SIMPULAN}

Berdassarkan hasil analisis dan pembahasan maka dapat disimpulkan sebagai berikut. Variabel bebas (ketimpangan pendapatan, tata kelola pemerintahan, dan korupsi) secara simultan atau bersama-sama berpengaruh terhadap tingkat kemiskinan. Maka dapat disimpulkan bahwa jika ketimpangan pendapatan, tata kelola pemerintahan, dan korupsi meningkatkan secara bersama-sama maka Tingkat Kemiskinan akan meningkat. Variabel Ketimpangan Pendapatan secara parsial berpengaruh signifikan terhadap Tingkat Kemiskinan. Maka dapat disimpulkan jika semakin meningkat ketimpangan pendapatan akan mengakibatkan semakin meningkat juga Tingkat Kemiskinan di Indonesia. Variabel Tata Kelola Pemerintahan secara parsial berpengaruh signifikan terhadap Tingkat Kemiskinan. Maka dapat disimpulkan jika semakin meningkat kinerja buruk pada pemerintahan akan mengakibatkan semakin meningkat juga Tingkat Kemiskinan di Indonesia. Variabel Korupsi secara parsial berpengaruh signifikan terhadap Tingkat Kemiskinan. Maka dapat disimpulkan jika semakin meningkat korupsi akan mengakibatkan semakin meningkat juga Tingkat Kemiskinan di Indonesia. Variabel bebas yang paling dominan berpengaruh terhadap Tingkat Kemiskinan adalah Tata Kelola Pemerintahan dengan sumbangan efektif, dibandingkan dengan variabel Ketimpangan pendapatan dan korupsi . hal tersebut menunjukkan semakin tinggi tata kelola pemerintahan yang buruk maka tingkat kemiskinan di Indonesia akan semakin meningkat.

\section{DAFTAR PUSTAKA}

Abdullah, Rusli. (2013), Faktor-Faktor yang Mempengaruhi Ketimpanga Pendapatan di Jawa Tengah. Skripsi : Fakultas Ekonomi Universitas Negeri Semarang.

Agus, Dwiyanto. 2005. Menunjukkan Good Governance melalui pelayananpublik. Pustaka Pelajar. Yogyakarta. 
Arvianto, Toni. 2017. Analisis Data Panel Ketimpangan Pendapatan Provinsi Jawa Tengah Tahun 2011-2015 dan Faktor-Faktor yang Mempengaruhinya. Skripsi: Fakultas Ekonomi dan Bisnis Universitas Muhammadiyah Surakarta.

Badan Pusat Statistik, Official website, available at www.bps.go.id.

Baldwin, Robert E. 1986; Pembangunan dan Pertumbuhan Ekonomi, terjemahan. St. Dianjung, PT Bina Aksara Jakarta.

Chetwynd, E, Chetwynd, F, \& Spector, B. 2003. Corruption and Poverty : A Review of Recent Literature, Washington DC.

Dwipayana , AAGN. ARI. 2003. Membangun Good Governance Raja Gravindo Pustaka, Jakarta.

Franciari, P.S. 2013. Analisis Hubungan IPM, Kapastitas Fiskal, dan Korupsi terhadap Kemiskinan di Indonesia (Studi kasus 38 Kabupaten / Kota di Indonesia tahun 2008 dan 2010). Diponegoro Journal Of Economics.

Fathia, Syahrani. 2018. Analisis Pengaruh Tata Kelola Pemerintahan yang Baik (Good Government Governance) dan Tingkat Penerimaan Pajak Terhadap Pertumbuhan Ekonomi. Skripsi : Fakultas Ekonomi dan Bisnis Universitas Lampung Bandar Lampung.

Gaol, Marlina Lumban. 2016. Pengaruh Good Governance Terhadap Perumbuhan Ekonomi di ASEAN. Skripsi : Fakultas Ekonomi dan Bisnis Universitas Diponegoro Semarang.

Indonesia Governance Index, Official website, available at www.kemitraan.or.id.

Juniadi Soewartojo. 1997. Korupsi, Pola Kegiatan, dan Penindakannya Serta Pengawasan dan Penanggulangannya. Balai Pustaka : Jakarta.

Karsona, Agus Mulya. 2011. Pengertian Korupsi dalam buku pendidiksn anti korupsi untuk perhatian

Kuncoro Mudrajad , 2000. Ekonomi Pembangunan Teori. Masalah dan kebijakan UPP AMP YKKN.

Pasaribu, Rowland B. F. (2011). Bab 13 Tata Kelola Pemerintahan.

Patra, Junaidi I Ketut. (2017). Korupsi, Pertumbuhan Ekonomi dan Kemiskinan di Indonesia. Jurnal : Fakultas Ekonomi dan Bisnis Universitas Muhammadiyah Surakarta. 
Bharanomics

Vol. 1 No. 22021

Lailatul Khasanah, Tingkat Kemiskinan di Indonesia

Prastyo, Ait Agus. (2010). Analisis Faktor-Faktor yang Mempengaruhi Tingkat Kemiskinan. Skripsi : Fakultas Ekonomi Universitas Diponegoro Semarang.

Ritonga, H Amanangun. 2003. Perhitungan penduduk miskin provinsi Sumatera Utara, susu SEMEK.

Taharah, Shofia. (2018). Skripsi : Ketimpangan Pendapatan di Daerah Istimewa Yogyakarta Tahun 2009 - 2015. Fakultas : Ekonomi Unibersitas Islam Indonesia.

Wahyuni, Eni. (2018). Pengaruh Tata Kelola Pemerintahan dan Korupsi terhadap tingkat Kemiskinan di Indonesia. Skripsi : Fakultas Ekonomi dan Bisnis Universitas Airlangga Surabaya. 